\title{
Makna Komunikasi Simbolik di Kalangan Pengguna Tato Kota Bandung
}

\author{
Gumgum Gumilar
}

\begin{abstract}
The aim of this research is to give result qualitative data through phenomenological approach and symbolic interaction about tattoos among its users. The focus of this research includes its development, motivation and the process of making tattoo, symbolic meaning and impression management were done in communication among tattoo users in Bandung. The research informant in this research was 24 tattoo permanent users with using purposive sampling.

The data collecting used in this research were observation, depth interview and documentation/ archive study. The result of this research showed that tattoo users could be categorized based on: Reasons, contact and immanent tattoo users; motive, past and future orientation tattoo users; design, classical, modern, and contemporary tattoo users; Tattoo placing, open and close tattoo users, and studio preferences, safe and risk tattoo users. In addition, tattoo artists could be categorized in; the period of profession, past and current tattoo artist; the tool in making tattoo, traditional and modern; the process of tattooing, safe and risk; skills, independent learner artist and special learning learner artist; the place of tattoo making, professional and street vendor artist.
\end{abstract}

Kata kunci: tato, komunikasi simbolik, makna

\section{Pendahuluan}

Tubuh, bagi sebagian orang, menjadi media tepat untuk berekspresi dan bereksperimen. Tak heran jika kemudian timbul aktivitas dekorasi seperti tato, Piercing dan Body Painting, eksploitasi ini untuk sebagian besar pelakunya ditujukan untuk gaya dan pernyataan pemberontakan. Jika awalnya orang melakukan eksploitasi tubuh untuk tujuan yang lebih khusus, misalkan untuk identitas pada suatu budaya tertentu, kini eksplotasi tubuh melalui tato, piercing dan body painting berkembang karena mode dan gaya hidup. Menurut Bruner (1986), posisi tubuh menjadi sangat vital karena ia merupakan ruang perjumpaan antara individu dan sosial, ide dan materi, sakral dan profan, transenden dan imanen. Tubuh dengan posisi ambang seperti itu tidak saja disadari sebagai medium bagi merasuknya pengalaman ke dalam diri, tetapi juga merupakan medium bagi terpancarnya ekspresi dan aktualisasi diri. Bahkan, lewat dan dalam tubuh, pengalaman dan ekspresi terkait secara dialektis.

Tato adalah gambar atau simbol pada kulit tubuh yang diukir dengan menggunakan alat sejenis jarum. Biasanya, gambar dan simbol itu dihias dengan pigmen berwarna-warni. Dulu, orang-orang masih menggunakan teknik manual dan dari bahan-bahan tradisional untuk membuat tato. 
Orang Eskimo, misalnya, memakai jarum dari tulang binatang. Sekarang, orang-orang sudah memakai jarum dari besi, yang kadang-kadang digerakkan dengan mesin untuk mengukir sebuah tato. Kuilkuil Shaolin menggunakan gentong tembaga yang panas untuk mencetak gambar naga pada kulit tubuh. $^{2}$

Menurut Ady Rosa dalam penelitiannya mengenai "Eksistensi Tato Mentawai," selama ini diyakini bahwa tato tertua ditemukan di Mesir sekitar tahun 1300 SM. Dari penelitian yang dilakukannya diketahui bahwa tato Mentawai telah ada sejak 1500 tahun sampai 500 tahun sebelum Masehi. Jadi, bisa dikatakan tato Mentawai merupakan tato tertua di dunia.

Fenomena tato bukan dilahirkan dari sebuah tabung dunia yang bernama modern dan perkotaan. Secara historis, tato lahir dan berasal dari budaya pedalaman, tradisional, bahkan dapat dikatakan kuno (Olong, 2006: 8). Keberadaan tato pada masyarakat modern perkotaan mengalami perubahan makna. Tato berkembang menjadi budaya populer atau budaya tandingan yang oleh audiens muda dianggap simbol kebebasan dan keragaman. Akan tetapi, kalangan tua melihat sebagai suatu keliaran dan berbau negatif. Dengan demikian, tato akan sangat tergantung pada tiga konteks pemaknaan, yakni kejadian historis, lokasi teks, dan formasi budaya. Akibatnya, kini budaya pop menjadi seperti lapangan perang semiotik antara sarana inkorporasi dan sarana resistensi, antara pengangkat makna yang diusung, kesenangan dan idetitas sosial yang diperbandingkan dengan yang telah ada.

Tato belakangan ini menjadi mode. Bila semula tato merupakan bagian budaya ritual etnik tradisional, kini berkembang menjadi bagian kebudayaan pop. Pada saat tato tradisional terancam punah, tato yang menjadi bagian kebudayaan pop semakin tertera di tubuh-tubuh manusia modern dan semakin disenangi. Karenanya, tidak perlu heran melihat artis-artis atau kalangan selebritis seperti Ayu Azhari, Becky Tumewu, Jajang C Noer, Karenina, Anjasmara, Cut Keke dan banyak lagi artis lain, menjadikan tato sebagai identitas yang melekat pada dirinya.
Eksistensi tato selama ini dianggap sebagai bagian dari penyimpangan. Tato masih merupakan bagian dari tindakan yang keluar dari rel-rel kaidah dan nilai-nilai yang berlaku di masyarakat. Pada masyarakat Indonesia, kecuali kota-kota besar, konformitas masih sangat kuat di mana anak muda dianggap normal, ganteng, dan alim, apabila rapi, bersih, tidak ada tato, tak bertindik, dan lain-lain. Jika terjadi penyimpangan sedikit saja seperti telinga atau hidung yang ditindik, maka akan mengakibatkan gunjingan dan celaan yang cepat menyebar ke mana-mana. Oleh karena itu, tidaklah mengherankan jika gaya-gaya anak muda seperti itu akan cepat-cepat dianggap sebagai sesuatu yang negatif(Olong, 2006: 34-35).

\section{Metode}

Penelitian ini menggunakan pendekatan kualitatif dengan metode fenomenologis. Moleong (2006) mensintesiskan beberapa definisi penelitian kualitatif bahwa penelitian kualitatif adalah penelitian yang bermaksud untuk memahami fenomena tentang apa yang dialami oleh subjek penelitian, misalnya perilaku, motivasi, tindakan, dll, secara holistik, dan dengan cara deskripsi dalam bentuk kata-kata dan bahasa, pada suatu konteks khusus yang alamiah dan dengan memanfaatkan berbagai metode alamiah.

Penelitian ini difokuskan pada pengguna tato permanen dengan jumlah sebanyak 24 informan. Penentuan informan dilakukan secara purposive. Informan dalam penelitian ini terbagi menjadi dua bagian, yaitu pertama, pengguna tato di kota Bandung yang terdiri 13 orang pengguna tato. Kedua, adalah 11 informan yang merupakan seniman tato, yaitu orang yang bekerja membuat tato,

\section{Hasil Penelitian}

\subsection{Perkembangan Tato di Kota Bandung}

Perkembangan tato di kota Bandung telah dimulai sejak 1960, dengan munculnya seniman tato pertama, yaitu Aceng Tato, yang telah menjadikan tato sebagai profesi yang dijalaninya 
Terakreditasi Dirjen Dikti SK No. 56/DIKTI/Kep/2005

sampai sekarang. Selain Aceng, terdapat empat orang lainnya yang dikenal sebagai seniman tato dalam periode 1970-1980, yakni Atang Tato di Braga, Cian Bie dan Jojon di daerah Sukamanah, serta Cucu di Bojongloa. Kelima orang ini disebutsebut sebagai sesepuhnya seniman tato di Kota Bandung. Kemudian, muncul Pian di Kebonjayanti, Kiaracondong, Hafid di Gg. Nana Rohana, Ayi di Cisitu Dago, dan Farli di Majalaya.

Ada dua hal yang disebut sebagai masa krisis, bahkan masa kelam seniman tato, yakni tahun 19831985, saat terjadi peristiwa penembakan misterius, yakni pembunuhan terhadap para preman dan gali, yang diidentikkan dengan penggunaan tato di tubuh mereka. Kemudian, tahun 1998-1999, ketika krisis moneter melanda Indonesia, dilanjutkan dengan naiknya Gus Dur sebagai Presiden Republik Indonesia. Masa ini merupakan masa sulit bagi seniman tato masa lalu, tetapi menjadi momentum kebangkitan seniman tato masa kini yang terus berkembang sampai saat ini.

\subsection{Tato sebagai Komunikasi Simbolik}

Tato merupakan karya seni yang bermuatan simbol. Pemaknaan terhadap simbol merupakan bagian integral dan interaksi dari berbagai pola pikiran dan tindakan komunikasi yang kemudian menjadikan kesepakatan. Dalam komunikasi, tentunya dibutuhkan struktur material, seperti bentuk fisik, warna, dan suara sebagai penyampai.

Pada dasarnya, setiap individu manusia adalah unik (einmalig), karena masing-masing dari mereka mempunyai pengalaman masa lalu yang menjadi pegangan dan ingatan yang berbeda-beda. Akan tetapi, pada bagian luar yang tampak adalah keseragaman, meski jika dikaji lebih lanjut perbedaan pada tiap individu akan semakin tampak. Hal ini tercermin pada tato, di mana ratarata terdapat keseragaman gaya, desain dari yang sederhana dan umum, seperti gambar mawar, tengkorak, hati, naga. Jika ditilik lebih jauh, maka ada nuansa perbedaan, mulai dari motivasi tato berdasar pengalaman masa lalu, proses tato, hingga kesukaan warna yang dipilih.

Berbagai pilihan desain dan penempatannya pada tubuh mengungkapkan ketertarikan, nilai yang dianut, hingga tingkah laku. Dapat pula dilihat bahwa tato merupakan indikasi pilihan rasa. Penciptaan simbol merupakan bukti manusia mempunyai akal budi yang kemudian menciptakan kebudayaan.

Proses yang dilakukan manusia secara arbitrer untuk menjadikan hal-hal tertentu untuk mewakili hal-hal lainnya, bisa disebut proses simbolik (Hayawaka, 1998:96). Simbol adalah sesuatu yang digunakan dengan sengaja untuk maksud sesuatu yang lain. Simbol juga merupakan suatu unit yang paling mendasar dalam komunikasi (Blake dan Haroldsen, 1979:7). Simbol atau lambang adalah sesuatu yang digunakan untuk menunjuk sesuatu yang lain, berdasarkan kesepakatan sekelompok orang (Mulyana, 2000:84).

Tato berfungsi sebagai simbol, tanda kenal, atau hiasan berupa suatu sistem penandaan atau sistem tanda-tanda visual yang meliputi:

(1) Simbol, merupakan tanda yang diwujudkan sebagai bahasa rupa, lewat gambar-gambar sebagai petunjuk yang telah disepakati bersama. Beberapa motif yang berfungsi sebagai simbol, terbentuk karena adanya hubungan antara falsafah hidup yang dirumuskan secara konvensional dan diungkapkan kembali melalui bentuk-bentuk visual.

Motif tato yang dipergunakan oleh informan, berfungsi sebagai simbol yang sarat dengan makna, seluruh pengguna tato yang menjadi informan menentukan motif yang akan dibuat ditubuhnya berdasarkan makna yang ada pada dirinya dan ingin diungkapkan dalam desain ragam tato. Misalnya, motif matahari yang dipergunakan Putri merupakan simbol yang bermakna mendalam mengenai kehidupan masa lalunya, juga tato yang dibuat Temmy ketika bergabung dengan salah satu kelompok genk bermotor di Kota Bandung.

(2) Indeks, merupakan suatu tanda yang punya kaitan dekat dengan apa yang diwakilinya, atau mempunyai hubungan timbal balik. Dalam penelitian ini, motif yang termasuk indeks, antara lain, penggunaan tato bertuliskan inisial yang memiliki makna tertentu untuk 
penggunanya, seperti tato yang ada di lengan kiri Reza, atau tulisan nama anak dan istri yang dibuat oleh Aldy.

(3) Ikon, merupakan unsur tato yang memiliki kemiripan bentuk dengan benda yang diwakilinya. Motif tato berdasarkan gambar wajah atau potret seseorang merupakan contoh dari tato sebagai Ikon. Beberapa informan membuat tato di tubuhnya dengan motif ini, seperti tato di tubuh Dada, Aep, Kicha, Deni, dan Andre.

(4) Legisign, suatu tanda yang didasarkan atas aturan atau hukum, merupakan struktur (hukum) atau keberaturan. Sejumlah motif memanfaatkan garis-garis berulang yang sangat beraturan dan memiliki ketentuan yang pasti, seperti motif tato tradisional Maori yang dibuat ditubuh Ferdy dengan garis-garis tegas yang menjadi ciri khas tato tradisional Maori.

(5) Qualisign, merupakan tanda yang berdasarkan kepada sifat. Seperti warna merah, karena menyampaikan suatu kesan tertentu yang khas bagi warna tersebut. Warna tersebut bisa menjadi tanda untuk menyatakan beberapa hal yang berhubungan ekspresi keras, seperti bahaya dan berani. Pengguna tato memiliki minat tertentu terhadap warna yang mereka gunakan, Aldy lebih memilih warna hitam sebagai bentuk ungkapan hati, sedangkan Putri lebih ke warna orange dan Odie dominan warna coklat.

(6) Sinsign, merupakan tanda yang terbentuk melalui kreasi pribadi, berupa garis-garis yang lebih spontan, pribadi, dan unik. Banyak tato yang dibuat berdasarkan hasil kreativitas pengguna tato atau seniman tato tanpa meniru bentuk yang sudah ada. Odie lebih cenderung membuat tato hasil desainnya sendiri.

\subsection{Tato sebagai Perilaku Menyimpang}

Suatu perilaku dianggap menyimpang apabila tidak sesuai dengan nilai-nilai dan norma-norma sosial yang berlaku dalam masyarakat atau dengan kata lain penyimpangan (deviation) adalah segala macam pola perilaku yang tidak berhasil menyesuaikan diri terhadap kehendak masyarakat.
Menurut Budi Rajab, menyimpang tidaknya sebuah perilaku berkaitan dengan dan norma masyarakat, jika norma masyarakat menganggap perilaku itu tidak bisa diterima, maka disebutlan perilaku menyimpang, kalo bisa diterima maka perilaku itu tidak menyimpang. ${ }^{3}$

Becker (1984) mengungkapkan bahwa penyimpangan adalah sesuatu yang dikenali sebagai pelanggaran terhadap normar-norma. Ditambahkan pula olehnya bahwa kontribusi utama dari analisis interaksionisme simbolik adalah teori penandaan, yang menyatakan bahwa penyimpangan dan penyesuaian tidak berasal dari apa yang dikerjakan orang, namun bagaimana orang lain merespons tindakan-tindakan itu.

Pemakaian tato dianggap sebagai hal yang menyimpang (deviant). Sebelum tato dianggap sebagai suatu yang modis, trendy, dan fashionable seperti sekarang ini, gaya tersebut memang dekat dengan budaya pemberontakan. Anggapan negatif tentang penggunaan tato seakan semakin kuat dengan berbagai larangan agama terhadap rajah tubuh atau tato. Menggunakan tato dianggap sama dengan memberontak terhadap tatanan sosial yang ada dan akan dianggap sebagai tindakan penyimpangan (deviant). Sebab, tato dianggap salah satu bentuk pembebasan diri terhadap segala tabu dan norma-norma masyarakat yang mengikat.

Tato dapat dipandang sebagai suatu model pilihan hidup yang baru bagi anak muda, sehingga ketika anak muda tersebut mendapat yang selama ini tak mereka dapatkan di dalam kungkungan/ belenggu norma-norma masyarakat seakan mendapatkan pencerahan yang diharapkan mampu memperkuat proses pencarian diri mereka. Ketika tato telah menjadi pilihan maka nilai deviasi yang tersandang sebagai gaya hidup tertentu lamakelamaan akan terkikis.

Terkikisnya nilai deviasi atau difference culture tersebut tidak terlepas dari globalisasi budaya massa, di mana mengguritanya budaya tersebut mengancam adanya suatu sifat homogenitas (keseragaman) yang telah membentuk mainstream di dalam masyarakat. Dapat dikatakan bahwa nilai deviasi adalah entitas revolusi yang dapat menghancurkan hegemoni kelas, tradisi, gaya 
Terakreditasi Dirjen Dikti SK No. 56/DIKTI/Kep/2005

hidup, hingga selera lama yang telah mapan dan mendapat kesempatan umum (Olong, 2006:40).

Bagi kaum muda, tato dianggap bersifat atraktif, sesuai dengan jiwa muda mereka yang penuh semangat, ide kreativitas yang seakan semakin meledak-ledak ketika melihat suatu tatanan sosial kultural masyarakat yang terasa mengikat kebebasan dan terasa monoton.

Fenomena tato menjurus pada budaya pop karena ia mulai terikat oleh formula produksi yang telah diuji dan digunakan berbagai kalangan. Misalnya, iklan celana jeans dengan model yang menggunakan tato, musikus terkenal yang menggunakan tato. Dalam hal ini, tato maupun tindik, merupakan unsur pendorong semaraknya budaya pop dan budaya massa.

Terjadinya pergeseran makna tato pada masa kekinian merupakan pergeseran dari budaya tinggi ke budaya massa. Salah satu aspek dari proses terjadinya pergeseran tersebut adalah bahwa budaya tanding ataupun seni ritual telah semakin terintegrasi ke dalam enititas ekonomi.

"Tato itu dulunya eksklusif tetapi kemudian bisa dimasalkan dengan berbagai cara, strateginya bisa macam-macam, tetapi proses populerisasinya dilakukan, karena toh secara ekonomi menguntungkan..kalo yang saya tahu dalam populer culture, bila sesuatu komponen kultur yang tadinya eksklusif dan memang memiliki nilai ekonomis tinggi, biasanya dimasalkan"4

\subsection{Tato sebagai Komunikasi Ekspresif}

Komunikasi ekspresif dapat dilakukan secara sendirian atau berkelompok, komunikasi ini sebagai instrumen untuk menyampaikan perasaanperasaan (emosi) kita. Perasaan tersebut terutama dikomunikasi melalui pesan-pesan nonverbal. Perasaan sayang, peduli, rindu, simpati, sedih takut, prihatin, marah, dan benci dapat disampaikan dengan kata-kata, namun dapat juga dilakukan dengan nonverbal. Jika kita lihat dari motivasi yang menyebabkan seseorang menggunakan tato di tubuhnya, maka bisa dipastikan tato adalah bentuk dari komunikasi ekspresif ini. Tato adalah ungkapan perasaan atau emosi dari penggunanya. Perasaan sayang, benci, cinta, patah hati, dan kekecewaan diungkapkan dalam simbol-simbol yang ditatokan di tubuh.

Ungkapan cinta Aldy dan Irene, terukir di jari mereka, tato dengan nama keduanya menjadi ekspresi perasaan cinta tersebut. Begitu juga rasa sayang dan kebahagian Aldy atas kelahiran putra pertama mereka dituangkan dalam sebuah tato bertuliskan buah hatinya.

Rasa sayang dan kerinduan kepada bunda diekspresikan Putri dengan adanya nuansa bunga matahari disetiap tato yang ada ditubuhnya, Odie membuatnya tato dengan gambar hati berbalut bunga mawar yang merupakan desain tato milik ibunya. Ungkapan perasaan yang sama dilakukan Aldy dengan membuat tato bertuliskan Mother \& Father di dadanya.

Bukan hanya perasaan sayang dan rindu yang bisa dikomunikasikan melalui tato. Perasaan benci dan kekecewaan pun banyak diungkapkan lewat seni ini. Sebagai pelampiasan, tato digunakan untuk melarikan diri dari permasalahan yang ada, rasa sakit berguna sebagai katarsis yang dapat mengurangi beban di hati pengguna tato. Kekecewaan dan kesedihan yang dirasakan Ali dan Andre diungkapkan dengan membuat tato di tubuhnya, gambar tengkorak dan setan mengekspresikan perasaan tersebut.

\subsection{Tato sebagai Komunikasi Ritual}

Komunikasi ritual biasanya dilakukan secara kolektif. Seperti halnya penggunaan tato tradisional yang disebut rites of passage, di mana tato merupakan ritual dalam upacara-upacara pada masa peralihan di waktu krisis (rites of passage), seperti kelahiran, masa dewasa, perkawinan, dan kematian. Mereka yang masih menggunakan tato dalam komunikasi ritual tersebut menegaskan kembali komitmen mereka pada tradisi budaya. Pada fungsi religius, tato erat berhubungan dengan kegiatan upacara keagamaan. Tato bermotif religius diyakini dapat memberi makna dalam kehidupan masyarakat, khususnya pada pengguna akan terhindar dari segala gangguan roh-roh jahat.

Kegiatan ritual memungkinkan para pesertanya berbagi komitmen emosional dan menjadi perekat bagi kepaduan mereka, juga 
sebagai pengabdian kepada kelompok (Mulyana, 2000:27). Pengguna tato sebagai identitas pada kelompok tertentu merupakan bentuk dari komunikasi ritual, tato menjadikan mereka bagian yang tidak terpisahkan dari kelompok tersebut. Seseorang yang akan masuk kelompok tersebut harus menggunakan tato dengan simbol yang menandakan dia anggota baru, simbol yang digunakan akan berbeda jika dia berada pada tingkatan yang lebih tinggi dalam kelompok.

\subsection{Motivasi Menggunakan Tato}

Pengguna tato pasti memiliki tujuan atau alasan kenapa mereka memutuskan untuk menggunakan tato di tubuhnya. Tidak ada tingkah laku yang terjadi begitu saja tanpa ada alasan, pasti ada faktor-faktor anteseden, sebab musabab, pendorong, motivator, sasaran-tujuan, dan atau latar belakangnya. Faktor-faktor itu harus diletakkan dalam suatu kerangka saling hubungan yang bermakna agar kesemuanya terjamin mendapat tilikan yang cermat ketika melakukan pendeskripsian tingkah laku, dan agar deskripsi dilakukan memakai sistematika yang ajeg dan komunikatif.

Dari penelitian yang dilakukan, motivasi menggunakan tato di kalangan pengguna tato kota Bandung, antara lain :

Tato Membentuk Ingatan Mengenai Masa Lalu. Tato merupakan salah cara untuk mengabadikan kenangan seseorang, dengan tubuh sebagai medianya, tato akan terus melekat dalam diri penggunanya, dengan demikian kenangan itu pun akan terus bersamanya, di antaranya untuk mengenang orang tua.

Tato, sebuah Ekspresi Perasaan. Dari penelusuran yang peneliti lakukan terhadap pengguna tato di kota Bandung, peneliti menemukan beberapa pengguna tato di mana desain yang dibuatnya mencerminkan ekspresi dari perasaan sayang dan cinta, antara lain: ekspresi rasa sayang terhadap anak, ekspresi rasa sayang dan cinta terhadap istri, ungkapan sayang dan sakit hati karena cinta.

Tato sebagai Identitas. Identitas meliputi upaya mengungkapkan dan menempatkan individu-individu dengan menggunakan isyaratisyarat nonverbal seperti pakaian dan penampilan (Stone dalam Phelan, 1998)). Banyak komunitas yang menjadikan tato sebagai salah satu ciri komunitas mereka, walaupun tidak ada simbol tertentu yang jadi keharusan untuk ditatokan di tubuhnya, komunitas punk, genk motor, komunitas motor besar atau anak-anak band banyak yang menggunakan tato di tubuhnya sebagai salah satu ciri kelompok mereka, tetapi desain dan penempatannya tidak ada aturan mutlak.

Tato sebagai Seni dan Keindahan. Membuat tato untuk seni dan keindahan merupakan motivasi yang paling banyak disampaikan oleh informan. Motivasi inilah yang menyebabkan saat ini pengguna tato perempuan semakin banyak, KentTato Studio menerima $60 \%$ pengguna tato yang menjadi pelanggan adalah perempuan yang berniat memperindah tubuh mereka dengan membuat tato.

Tato sebagai Pelampisan Permasalahan. Rasa sakit diakibatkan proses penatoan merupakan media untuk melepaskan beban permasalahan, di

Tabel 1

Kategorisasi Pengguna Tato

\begin{tabular}{|l|l|l|l|l|}
\hline Alasan & \multicolumn{1}{|c|}{ Motif } & Desain & Penempatan & $\begin{array}{c}\text { Pemilihan } \\
\text { Studio }\end{array}$ \\
\hline$\bullet$ Imanen & $\bullet \begin{array}{l}\text { Orientasi masa } \\
\text { lalu }\end{array}$ & $\bullet$ Klasik & $\bullet$ Terbuka & $\bullet$ Aman \\
\hline Kontak & $\bullet \begin{array}{l}\text { Orientasi masa } \\
\text { datang }\end{array}$ & $\bullet$ Modern & $\bullet \quad$ Tertutup & $\bullet$ Berisiko \\
\hline & \multicolumn{1}{|l|}{ Kontemporer } & & \\
\hline
\end{tabular}




\section{Tabel 2}

Kategorisasi Seniman Tato

\begin{tabular}{|c|c|c|c|c|}
\hline $\begin{array}{c}\text { Lama } \\
\text { menjalani } \\
\text { Profesi }\end{array}$ & $\begin{array}{c}\text { Peralatan yang } \\
\text { digunakan }\end{array}$ & $\begin{array}{c}\text { Proses } \\
\text { Penatoan }\end{array}$ & Keahlian & $\begin{array}{c}\text { Tempat } \\
\text { Penatoan }\end{array}$ \\
\hline - Masa lalu & • Tradisional & - Aman & $\checkmark$ Otodidak & $\checkmark \quad$ Profesional \\
\hline - Masa Kini & $\bullet \quad$ Modern & $\checkmark \quad$ Beresiko & Belajar Khusus & $\checkmark \quad$ Kaki Lima \\
\hline
\end{tabular}

samping itu beberapa informan membuat tato karena frustrasi.

\subsection{Kategorisasi Pengguna Tato}

Hasil penelitian memperlihatkan bahwa pengguna tato dapat dikategorikan berdasarkan: Alasan, pengguna tato imanen dan pengguna tato kontak; Motif, pengguna tato dengan orientasi masa lalu dan pengguna tato berorientasi masa datang; Desain, Pengguna tato klasik, pengguna tato modern dan pengguna tato kontemporer; Segi penempatan tato, pengguna tato terbuka dan tertutup; Pemilihan studio, pengguna tato aman dan pengguna tato berisiko.

Sedangkan seniman tato dapat di kategorikan sebagai berikut: Lama menjalani profesi, seniman tato masa lalu dan masa kini; Peralatan yang digunakan, seniman tato tradisional dan seniman tato modern; Proses Penatoan, seniman tato aman dan seniman tato berisiko; Keahlian, seniman tato otodidak dan belajar khusus; Tempat penatoan, seniman tato profesional dan seniman tato kaki lima.

\subsection{Interaksi di antara Pengguna Tato}

Komunikasi penting dilakukan pada seluruh proses penatoan, seniman tato maupun pengguna tato berdiskusi untuk menghasilkan rancangan dan hasil tato yang memuaskan kedua belah pihak, komunikasi yang baik akan menghasilkan sebuah kesepakatan dan kesamaan makna.

Dalam proses penatoan, terjadi komunikasi yang intens di antara pengguna tato dengan seniman tato, komunikasi dilakukan agar tercapai kesepakatan hasil seperti apa yang ingin dihasilkan. Jika kita gambarkan pola komunikasi

\section{Gambar 1: Pola Komunikasi dalam Proses Penatoan}

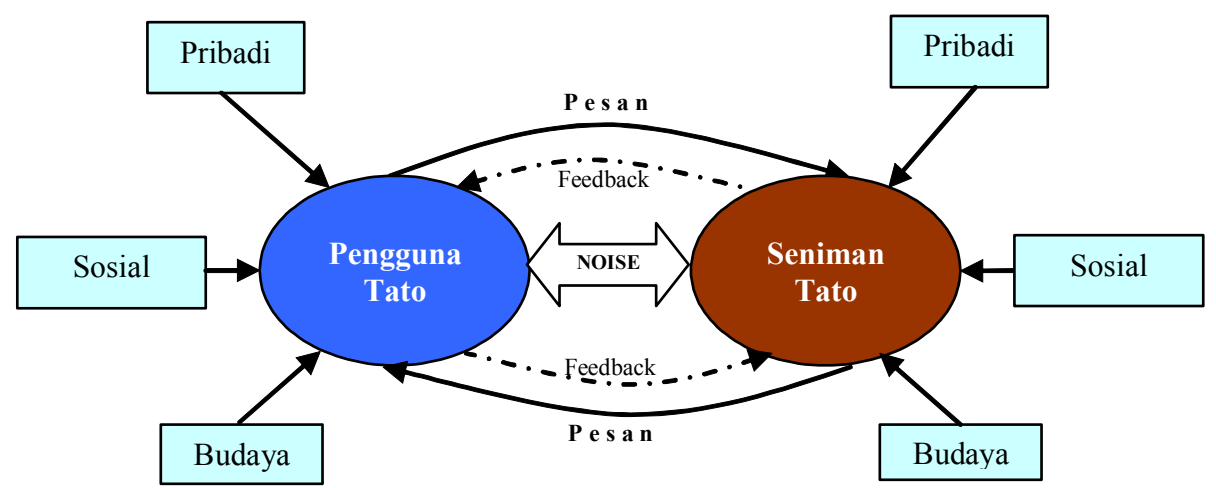


antara pengguna tato dengan seniman tato, sebagai pada Gambar 1.

Gambar 1, memperlihatkan komunikasi yang dilakukan antara pengguna tato dengan seniman tato atau di antara sesama pengguna tato lebih pada menciptakan hubungan antarpribadi. Pengguna tato maupun seniman tato melakukan komunikasi secara langsung, biasanya tatap muka, saling menyampaikan pesan berkenaan dengan aktivitas pembuatan tato yang mereka lakukan. Pada suatu kesempatan, pengguna tato bertindak sebagai pengirim pesan, dan seniman tato sebagai penerima pesan, sedangkan pada kesempatan lain pengguna tato bertindak sebagai penerima pesan dan seniman tato sebagai pengirim pesan. Keduanya memberikan umpan balik (feedback) secara langsung, dan komunikasi berlangsung tidak statis.

Proses penyampaian dan penerimaan pesan yang dilakukan keduanya merupakan suatu proses interaktif yang dipengaruhi oleh faktor-faktor dari dalam individu itu sendiri maupun faktor luar. Faktor yang memengaruhi, antara lain, pribadi/ individu, sosial, dan budaya. Faktor-faktor tersebut mempengauhi kedua belah pihak yang melakukan komunikasi dengan muatan yang berbeda.

Pribadi/Individu. Pengaruh pribadi/individu dalam pola komunikasi yang dilakukan di atas meliputi faktor-faktor motivasi pengguna tato, keyakinan membuat tato ditubuh, keahlian seniman tato dalam membuat desain tato, serta kreativitas seniman tato. Pengaruh sosial lebih pada faktorfaktor; penerimaan keluarga, teman, dan masyarakat sekitar kita terhadap seni tato; keanggotaan kita dalam kelompok sosial; konsep diri kita; bagaimana peran yang akan kita jalani dan bagaimana kita memaknai hubungan kita dalam komunikasi yang dilakukan (antara pengguna tato dengan seniman tato). Aspek Budaya dipengaruhi oleh faktor nilai, norma, dan aturan yang memengaruhi komunikasi kita, dan pandangan agama.

Aspek-aspek yang memengaruhi di atas bisa menjadi faktor yang memperkuat komunikasi yang dilakukan, tetapi juga bisa menyebabkan gangguan (noise) terhadap komunikasi yang sedang berlangsung. Gangguan tersebut dapat menjadi kendala tercapainya kesepakatan dan kesamaan makna, sehingga diperlukan komunikasi yang lebih intens dan saling pengertian.

\subsection{Pembentukan Konsep Diri Pengguna Tato}

Konsep diri didefinisikan secara umum sebagai keyakinan, pandangan, atau penilaian seseorang terhadap dirinya. Baik buruk atau positifnegatifnya pandangan kita terhadap diri sendiri, sering kita terapkan konsep diri kita dalam tingkah laku. Pengguna tato mempunyai kecenderungan untuk bertingkah laku sesuai dengan konsep dirinya, dalam bahasa psikologi disebut nubuat yang dipenuhi sendiri.

Beberapa pengguna tato dengan konsep diri yang negatif adalah: Pertama, pengguna tato sangat peka terhadap kritik. Dia mudah tersinggung dan tidak tahan terhadap apa yang dikatakan orang tentang dirinya, apabila ada orang yang mengritik penggunaan tato di tubuhnya, maka dia akan marah dan menganggap kritik tersebut sebagai suatu hinaan. Pengguna tato dengan konsep diri negatif seperti ini lebih tertutup dan jarang bergaul dengan anggota masyarakat lain, mereka lebih senang berada dalam komunitasnya sendiri.

Kedua, pengguna tato yang memiliki konsep diri negatif sangat senang jika ada orang yang memuji dirinya, walaupun dia berusaha menyembunyikan perasaan tersebut, tetapi sebuah pujian akan diterimanya dengan antusias. Pengguna tato tipe ini senang menjadi pusat perhatian, segala macam bentuk tato yang ada di tubuhnya dijadikan alat untuk membuat dirinya menjadi pusat perhatian.

Ketiga, karena kesenangan terhadap pujian orang lain, pengguna tato dengan konsep diri negatif, cenderung mencela, mengeluh, atau meremehkan apa pun dan siapa pun. Diri memberikan pandangan negatif terhadap pandangan orang lain tentang dirinya, terutama pandangan negatif. Sulit untuk menghargai orang lain dan memberikan pujian terhadap orang lain, dia merasa hanya dirinyalah yang layak mendapat 
Terakreditasi Dirjen Dikti SK No. 56/DIKTI/Kep/2005

pujian. Sikap ini disebut hiperkritis.

Empat, pengguna tato dengan konsep diri yang negatif cenderung merasa dirinya tidak disenangi orang lain. Merasa tidak diperhatikan. Hal ini menyebabkan pengguna tato tersebut sulit untuk bergaul dengan orang lain, dia menggap orang lain itu musuh yang tidak bisa menerima dirinya, karenanya sangat sulit untuk mendapatkan teman atau sahabat, karena dia sendiri telah menjaga jarak dengan orang lain. Situasi itu dirasakan bukanlah salah dirinya, dia hanyalah sebagai korban dari sistem kemasyarakatan (sosial) yang sarat dengan nilai dan norma.

Kelima, pengguna tato dengan konsep diri yang negatif tidak percaya dengan dirinya sendiri. Dia merasa tidak dapat bersaing dengan orang lain. Tato dijadikan alat pembelaan diri atas keengganannya untuk bersaing memperoleh prestasi. Dia pesimis dengan dirinya sendiri.

Selain konsep diri negatif, terdapat pengguna tato dengan konsep diri positif. Tanda pengguna tato dengan konsep diri positif adalah:

(1) Perilakunya dengan menggunakan tato di tubuh, tentu akan menimbulkan masalah, tetapi dia yakin akan kemampuannya mengatasi masalah. Salah satunya adalah memperlihatkan perilaku yang baik.

(2) Pengguna tato dengan konsep diri yang positif merasa dirinya merupakan bagian dari masyarakat. Dia merasa setara dengan anggota masyarakat lain. Tato di tubuhnya bukanlah alasan merasa diri lebih rendah dari anggota masyarakat yang lain.

(3) Setiap orang senang dipuji, termasuk pengguna tato. Pujian diterimanya dengan tanpa rasa malu. Tetapi, dia tidak merasa dirinya sebagai pusat perhatian. Dalam komunikasi dan interaksi orang lain harus mendapat perhatian yang sama. Ketika orang memuji dirinya maka dia akan rendah hati dan kembali memuji lawan bicaranya. Dia merasa dalam interaksi semua orang memiliki hak yang sama.

(4) Pengguna tato dengan konsep diri positif menyadari bahwa setiap orang memiliki perasaan yang berbeda, keinginan dan perilaku yang tidak seluruhnya disetujui masyarakat. Ia merasa wajar jika ada anggota masyarakat memberi penilaian negatif terhadap perilakunya menggunakan tato, karena dia juga yakin ada anggota masyarakat lain yang tidak mempermasalahkannya.

(5) Pengguna tato dengan konsep diri positif, mampu memperbaiki dirinya. Dia sanggup menilai seperti apa dirinya. Apabila ada aspek dalam dirinya yang tidak disenangi, maka dia akan mengubahnya. Untuk memperbaiki konsep dirinya, bukan dengan menjauhi masyarakat, tetapi dengan membuktikan bahwa tato yang ada di tubuhnya bukan identifikasi dari perilaku negatif. Antara tato dan perilaku keseharian tidak dapat disamakan.

Konsep diri yang paling dini, umumnya di pengaruhi oleh keluarga dan orang-orang dekat lainnya disekitar kita (Mulyana, 2000:8). Orang tua memberikan pendapatnya mengenai tato yang digunakan, begitu juga anggota keluarga yang lain dan orang-orang di sekitar kita.

George Herbert Mead mengatakan, setiap manusia mengembangkan konsep dirinya melalui interaksi dengan orang lain dalam masyarakat dan itu dilakukan lewat komunikasi. Jadi, kita mengenal diri kita lewat orang lain, yang menjadi cermin yang memantulkan bayangan kita. Charles H. Cooley. menyebut konsep diri itu sebagai the looking glass-self, yang secara signifikan ditentukan oleh apa yang seseorang pikirkan mengenai pikiran orang lain terhadapnya, jadi menekankan pentingnya respons orang lain yang diinterpretasikan secara subjektif sebagai sumber primer data mengenai diri (Mulyana, 2000:10).

\subsection{Pengelolaan Kesan}

Goffman mengasumsikan bahwa ketika orangorang berinteraksi, mereka ingin menyajikan suatu gambaran diri yang akan diterima orang lain. Dia menyebut upaya tersebut sebagai impression management atau pengelolaan kesan. Ketika berinteraksi atau berkomunikasi, seseorang akan mengelola didirnya agar tampak seperti apa yang dikehendakinya, sementara juga orang lain yang 
Gambar 2: Model Pengelolaan Kesa

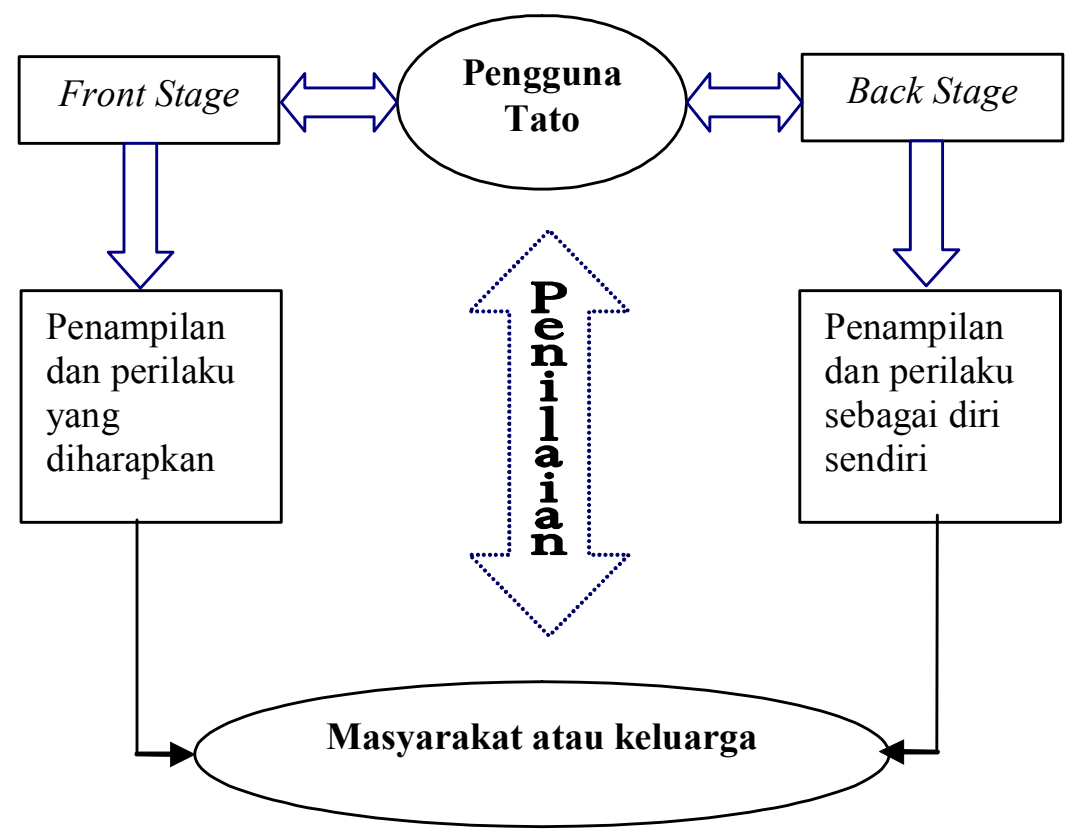

menjadi mitra komunikasinya melakukan hal yang sama. Oleh karenanya, setiap orang melakukan petunjukan bagi orang lain, sehingga ia menjadi aktor yang menunjukkan penampilannya untuk membuat kesan bagi lawannya.

Pengelolaan kesan yang dilakukan pengguna tato sangat berkaitan dengan anggapan negatif yang masih melekat di masyarakat. Tato masih dianggap sebagai perilaku yang menyimpang, sehingga pengguna tato lebih nyaman menutupi tato di tubuhnya jika berinteraksi dengan masyarakat. Jika kita gambarkan, apa yang dilakukan oleh pengguna saat berinteraksi dengan masyarakat menempatkan diri pada bagian depan panggung (front stage), yaitu suatu peran yang memang diinginkan oleh masyarakat. Pengaturan (setting) yang dilakukan oleh pengguna tato untuk panggung depan ini berkaitan dengan cara berpakaian dan cara berkomunikasi lisan. Dalam cara berpakaian, pengguna tato terutama perempuan memilih untuk menutupi bagian tubuhnya yang ditato jika berada pada lingkungan yang dianggapnya belum dapat menerima mereka, tetapi akan berbeda ketika mereka berada pada komunitas yang mengerti dengan keberadaan meraka.

Selain mengelola kesan dalam interaksi dengan orang lain yang tidak menggunakan tato melalui cara berpakaian, pengguna tato harus dapat membuktikan diri mereka dalam kehidupannya di masyarakat. Anggapan negatif di masyarakat tidak menjadikan konsep dirinya pun negatif, tetapi anggapan negatif tersebut di jawab dengan perbuatan yang memperlihatkan tato bukanlah ciri orang bermasalah dalam masyarakat.

Sebagian besar informan sepakat bahwa perilaku mereka di masyarakat dapat memperbaiki citra tato itu sendiri, keikutsertaan dalam setiap kegiatan sosial kemasyarakatan menjadi cara yang efektif untuk menjawab anggapan negatif yang ada di masyarakat. Jadi, selain mengelola kesan dengan cara berpakaian (penampilan) juga dengan memperlihatkan perilaku yang santun.

Pengelolaan kesan oleh pengguna tato juga dilakukan berkaitan dengan penerimaan dari keluarga, sebagian informan tidak mendapat 
penerimaan dari keluarga atas keputusannya untuk menggunakan tato di tubuhnya, atau pengguna tato merasa bahwa keluarganya akan menentang keputusan dia untuk menggunakan tato. Hal ini ditutupi dengan pengelolaan kesan, seakan mereka hidup pada bagian keluarga yang seperti mereka bayangkan atau mereka inginkan, mereka menutupi kenyataan sebenarnya bahwa mereka telah melakukan sesuatu yang bisa saja bertentangan dengan keinginan keluarga.

\section{Kesimpulan dan Saran}

Tato adalah produk budaya yang pada perkembangannya mengalami pergeseran makna, pada masyarakat tradisional tato merupakan identitas dalam masa peralihan (rites of passage), tato pada masa Orde Baru mengalami masa suram, terutama pada peristiwa penembakan misterius di mana preman, gali, dan penjahat, diidentikkan dengan tato yang digunakan di tubuhnya. Kini, tato dianggap sebagai seni dan keindahan, tato menjadi bagian dari budaya popular yang berkembang dalam masyarakat modern.

Pengguna tato pasti memiliki tujuan atau alasan kenapa mereka memutuskan untuk menggunakan tato di tubuhnya. Tidak ada tingkah laku yang terjadi begitu saja tanpa ada lasan, pasti ada faktor-faktor anteseden, sebab musabab, pendorong, motivator, sasaran-tujuan, dan atau latar belakangnya. Faktor-faktor itu harus diletakkan dalam suatu kerangka saling hubungan yang bermakna agar kesemuanya terjamin mendapat tilikan yang cermat ketika melakukan pendeskripsian tingkah laku, dan agar deskripsi dilakukan memakai sistematika yang ajeg dan komunikatif.

Komunikasi yang baik sangat diperlukan dalam sebuah proses penatoan, hubungan antarpribadi antara seniman tato dengan pengguna tato sangat penting untuk menghasilkan tato yang sesuai dengan keinginan, di samping keahlian dan kreativitas seniman tatonya serta ketersediaan alat yang menunjang unsur kesehatan. Komunikasi juga dipengaruhi oleh faktor-faktor sosial, seperti penerimaan keluarga, teman, dan masyarakat, keanggotaan kita dalam kelompok tertentu, konsep diri, peran yang dijalani, serta bagaimana memaknai hubungan antara pengguna tato.

Pengeloalan kesan dilakukan ketika pengguna tato berinteraksi dengan keluarga atau anggota masyarakat yang belum dapat menerima penggunaan tato dan masih menganggap negatif orang yang menggunakan tato. Pengelolaan kesan ini dapat dilakukan dengan penampilan, misalkan menutupi tato agar tidak terlihat langsung oleh orang lain atau dengan bertingkah laku sesuai dengan harapan keluarga dan masyarakat.

\section{Catatan Akhir}

1 Disarikan dari Tesis penulis di Pascasarjana Universitas Padjadjaran dengan Judul Fenomena Tato dan Pemaknaan Simbolik di Kalangan Pengguna Tato Kota Bandung (Studi Fenomenologi dan Interaksi Simbolik Mengenai Tato di Kalangan Pengguna Tato Kota Bandung. 2007.

2 Juliastri, Nuraini. \& Antariksa. Tato Antara Politik dan Keindahan Tubuh. Artikel dalam World Wide Web http://kunci.or.id.

3 Wawancara dengan Budi Rajab, 13 januari 2007

4 Wawancara dengan Budi Rajab, 13 januari 2007

\section{Daftar Pustaka}

Basrowi \& Sudikin. 2002. Metode Penelitian Kualitatif: Perspektif Mikro. Surabaya: Insan Cendikian.

Becker, S. Howard. 1997. "Becoming a Marihuana User" Kumpulan teori-teori Sosial dan Fenomenologi sampai Behavioral. Pascasarjana Unpad Bandung.

Black, Reed H. and Edwin O. Haroldsen. 1979. A Taxonomy of Concept in Communication. Hastings House. Publishers. New York.

Cassirer, Ernst. 1987. Manusia dan Kebudayaan: Sebuah Esei tentang Manusia. Diterjemahkan oleh Alois A. Nugroho. Jakarta: Gramedia.

Creswell, John W. 1998. Qualitative Inquiry and Research Design: Choosing Among Five Traditions. Sage Publication Inc. USA. 
Hayawaka, S.I. 1998. "Simbol-simbol.” Dalam Deddy Mulyana dan Jalaludin Rakhmat. Komunikasi Antarbudaya. Bandung: Remaja Rosdakarya.

Koentjaraningrat. 1985. Kebudayaan, Mentalitas, dan Pembangunan. Jakarta: Gramedia.

Littlejohn, Stephen W. 1996. Theories of Human Communication. Fifth Edition, Belmont California: Eadsworth Publishing Company.

Miller, J.C. 1997. The Body Art Book. New York: Barkeley Books.

Moleong, Lexy J. 2006. Metodologi Penelitian Kualitatif. Bandung: Remaja Rosdakarya.

Mulyana, Deddy. 2000. Ilmu Komunikasi: Suatu Pengantar. Bandung:Remaja Rosdakarya. Komunikasi dan Ilmu Sosial Lain Bandung: Remaja Rosdakarya.

Olong, HA. Kadir. 2006. Tato. Yogyakarta: PT. LKiS Pelangi Aksara.
Phelan, Michael P. And Scott A. Hunt. 1998. Prison Gang Members's Tatoos as identity Work: The Visual Communication of Moral Careers.University of Kentucky

Schutz, Alfred. 1972. The Phenomenological of The Social World. London: Heinemann Educational Book.

Van Zoest, Aart dan Panuti Sujiman (ed.). 1992 Serba-serbi Semiotika. Jakarta: Gramedia.

Wood, Julia T. 1998. Communications Mosaics. Belmont, California : Wadswort.

\section{Sumber lain:}

Gatra. 2001. Tato Mentawai Tertua di Dunia. No. 20. 2 April.

Kompas, Ady Rosa. 2001. 'Jenderal Tato'. Sabtu, 24 Februari

Rosa, Adi. 1994. Eksistensi Tato sebagai Salah Satu Karya Seni Rupa Tradisional Masyarakat Mentawai. Bandung: Tesis Institut Teknologi Bandung. 